\title{
ANALYSIS OF DISTRICT HEALTH FINANCING TO ACHIEVE MINIMUM HEALTH SERVICE STANDARD IN ROTE NDAO, EAST NUSA TENGGARA
}

\author{
Susana Bessie, Serlie K.A Littik, Jacob M. Ratu \\ Masters Program in Public Health, Faculty of Public Health, Universitas Nusa Cendana
}

\begin{abstract}
Background: The trend of budget allocation for the health sector in Rote Ndao, East Nusa Tenggara has increased in 2016 to 2018. In 2017, budget allocation commitment from the regional revenue and expenditure budget met the minimum required proportion. It has not impacted on achieving the health minimum service standard (MSS) target. This possibility is influenced by the sub-optimal implementation of the program. This study aimed to analyze the district health financing to achieve minimum health service standard in Rote Ndao, East Nusa Tenggara.

Subjects and Methods: This was a qualitative study conducted in Rote Ndao, East Nusa Tenggara. The main theme in this study was analysis of the district health financing to achieve minimum health service standard. The data were collected using secondary data by District Health Account approach. The data were analyzed descriptively.

Results: The largest health budget managers were Ba'a Hospital (54.66\% in 2016) and public health office (55.85\% in 2017). In 2016, the largest expenditure was Ba'a Hospital (54.66\%). In 2017, the largest expenditure was government health administration provider (73.26\%). In 2016 to 2017 , only a small number of priority programs in the health sector achieved MSS, such as maternal and child health, nutrition and prevention of infectious diseases, and elderly health programs. Programs that did not reach the MSS target were family planning, immunization, surveillance, non-communicable disease prevention, and health promotion. The proportion of expenditure for all programs was relatively small when compared to health service support.

Conclusion: Health budget spending in Rote Ndao in 2016 to 2017 has not been optimal in improving the performance of health program. It is necessary to increase the accuracy of budget allocation for direct activity.
\end{abstract}

Keywords: health financing, minimum service standards

\section{Correspondence:}

Susana Bessie. Masters Program in Public Health, Faculty of Public Health, Universitas Nusa Cendana, Kupang, East Nusa Tenggara. Email:alridjan@gmail.com. Mobile: +6281237128765 . 